\title{
Canadian Revue
}

Journal of canadienne de
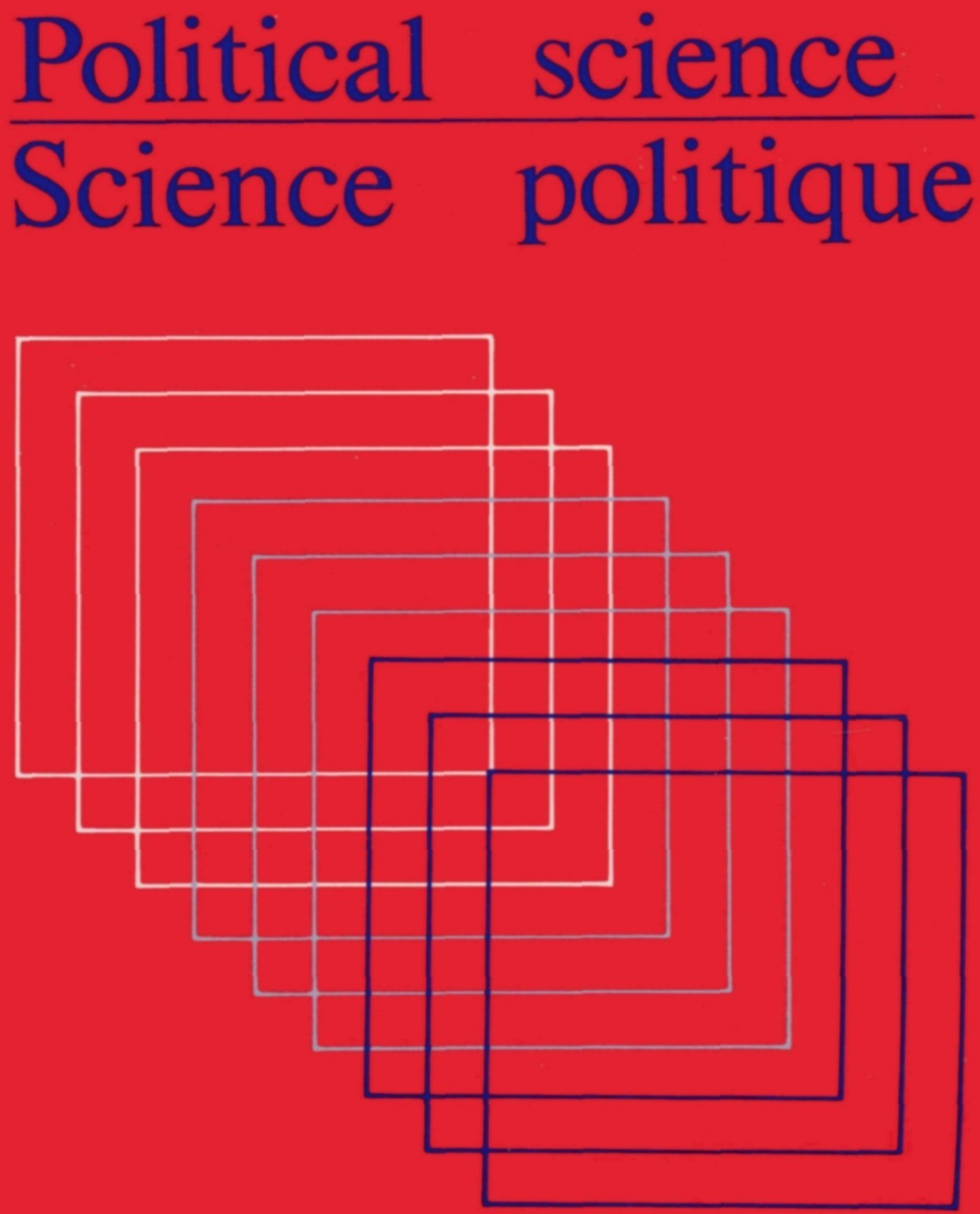

September 1984 septembre XVII:3 


\title{
Canadian Journal of Political Science / Revue canadienne de science politique
}

\section{EDITORIAL BOARD / COMITÉ DE RÉDACTION}

Robert Boardman (Dalhousie), co-editor Grace Skogstad (St. Francis Xavier), review editor

Herman Bakvis (Dalhousie), assistant editor

Jean Crête (Laval), codirecteur

Graciela Ducatenzeiler (Montréal), secrétaire à la rédaction et responsable des recensions

John McMenemy, managing editor/directeur de la gestion, Wilfrid Laurier University

ADVISORY BOARD / CONSEIL CONSULTATIF

André Bemard (Université du Québec à Montréal)

Richard Johnston (British Columbia)

Bahgat Korany (Montréal)

\author{
Vincent Lemieux (Laval) \\ William Mathie (Brock) \\ Janice Stein (Toronto) \\ Reginald Whitaker (Carleton)
}

Editorial correspondence in English should be directed to Professor Robert Boardman, Department of Political Science, Dalhousie University, Halifax, Nova Scotia B3H 4H6. Authors are requested to forward three copies of the manuscript together with three copies of an abstract of 100 words. All material must be double-spaced. Footnotes must be double-spaced and placed in a single listing at the end of the paper. Tables and diagrams must be submitted on separate pages. The manuscript will not be returned.

On doit adresser toute communication en français au sujet de la rédaction au Professeur Jean Crête, Département de science politique, Université Laval, Sainte-Foy, P.Q. GIK 7P4. Les auteurs envoient leur manuscrit, en trois exemplaires, accompagné d'un résumé, en trois exemplaires, ne dépassant pas 100 mots. Le tout doit être dactylographié à double interligne. Il faut que les notes apparaissent à double interligne, à la fin du texte, en ordre continu et sur des feuilles distinctes. Les tableaux et graphiques doivent être faits sur des pages séparées. Le manuscrit ne sera pas renvoyé.

Subscription and business correspondence should be directed to Wilfrid Laurier University Press, Wilfrid Laurier University, Waterloo, Ontario N2L 3C5. / Les communications à caractère commercial, y compris celles concernant les abonnements, doivent être adressées à: Wilfrid Laurier University Press, Wilfrid Laurier University, Waterloo, Ontario N2L 3C5.

The Journal acknowledges with gratitude the generous assistance of the Social Sciences and Humanities Research Council of Canada. / La Revue tient à remercier le Conseil de recherches en sciences humaines du Canada pour la généreuse subvention qu'il a bien voulu lui accorder.

INDEXED IN / INDEXÉE AU: International Political Science Abstracts / Documentation Politique Internationale; $A B C$ POL SCI (Advance Bibliography of Contents: Political Science and Government); Périodex: index analytique de périodiques de langue française; Sociological Abstracts; United States Political Science Documents; Arts \& Humanities Citation Index (A\&HCI); Current Contents/Arts \& Humanities; PAIS Foreign Language Index; Index to Canadian Legal Periodical Literature (partiallpartiel); Indian Book Review Digest (partiallpartiel); International Political Science Information Service; IBZ(Internationale Bibliographie der Zeitschriftenliteratur); IBR(Internationale Bibliographie der Rezensionen).

The headquarters of the Canadian Political Science Association is at the University of Ottawa, Ottawa, Canada KIN 6N5. / Le siège social de l'Association canadienne de science politique est à l'Université d'Ottawa, Ottawa, Canada K1N 6N5. Le siège social de la Société québécoise de science politique est à / The headquarters of the Société québécoise de science politique is at the Université du Québec à Montréal, Montréal, Canada H3C 3 P8.

(C) Canadian Political Science Association (I'Association canadienne de science politique) and/et la Société québécoise de science politique 1984

Published by / Publiêe par Wilfrid Laurier University Press for/pour the Canadian Political Science Association (l'Association canadienne de science politique) and/et la Société québécoise de science politique

CN ISSN 0008-4239

Second class mail registration / Courrier recommandé de deuxième classe \#4011 


\section{Contents / Sommaire}

The Political Wisdom of Sir John A. Macdonald

ROD PREECE 459

Aristotle on Acquisition

WAYNE H. AMBLER 487

L'aspect radical et révolutionnaire de la théorie sociale et politique de Popper

FRED EIDLIN 503

Hayek and Schmitt on the Rule of Law

F. R. CRISTI 521

Tribal Traditions and European-Western Political Ideologies: The Dilemma of Canada's Native Indians

MENNO BOLDT and J. ANTHONY LONG 537

The Eyes of Argus: The Political Art of Niccolo Machiavelli

GEORGE FEAVER 555

Public Policy-Making as Practical Reasoning

RONALD MANZER 577

\section{Note}

Nos journaux sont-ils compréhensibles?

GAËTAN TREMBLAY 595

Recensions / Reviews 607

Notices / A vis 659 